\title{
The VEGF inhibitor vatalanib regulates $A D$ pathology in 5xFAD mice
}

\author{
Seong Gak Jeon, Hyun-ju Lee, HyunHee Park, Kyung-Min Han and Hyang-Sook Hoe * (0)
}

\begin{abstract}
Alzheimer's disease (AD) is a highly prevalent neurodegenerative disease characterized by $A \beta$ accumulation and tau hyperphosphorylation. Epidemiological evidence for a negative correlation between cancer and AD has led to the proposed use of tyrosine kinase inhibitors (TKIs) such as dasatinib and masitinib for AD, with reported beneficial effects in the AD brain. The TKI vatalanib inhibits angiogenesis by inhibiting vascular endothelial growth factor receptor (VEGFR). Although changes in VEGF and VEGFR have been documented in $A D$, the effect of vatalanib on $A D$ pathology has not been investigated. In this study, the effects of vatalanib on tau phosphorylation and $A \beta$ accumulation in 5xFAD mice, a model of AD, were evaluated by immunohistochemistry. Vatalanib administration significantly reduced tau phosphorylation at AT8 and AT100 by increasing p-GSK-3 3 (Ser9) in 5xFAD mice. In addition, vatalanib reduced the number and area of $A \beta$ plaques in the cortex in $5 \times F A D$ mice. Our results suggest that vatalanib has potential as a regulator of AD pathology.
\end{abstract}

Keywords: Alzheimer's disease, Tau, Amyloid beta, 5xFAD mice, Vatalanib, Vascular endothelial growth factor, Tyrosine kinase inhibitor

\begin{abstract}
Alzheimer's disease (AD) is the most common progressive neurodegenerative disease. The accumulation of amyloid $\beta(\mathrm{A} \beta)$ plaques and neurofibrillary tangles (NFTs) in the brain is the neuropathological hallmark of $\mathrm{AD}$. $\mathrm{A} \beta$ plaques are formed from the accumulation of $\mathrm{A} \beta$ produced by sequential cleavage of amyloid precursor protein (APP) via $\beta$ - and $\gamma$-secretase, and NFTs are aggregates of hyperphosphorylated tau, which normally functions in microtubule stabilization. $A \beta$ plaque and NFT levels are both discriminators of and contributors to $\mathrm{AD}$ progression and are closely correlated with cognitive impairment in $\mathrm{AD}$ subjects [1]. Although $\mathrm{AD}$ and cancer share aging as a common factor, accumulating epidemiological evidence indicates a negative correlation between cancer and AD. This evidence has led to the proposed repurposing of cancer drugs of various mechanisms of
\end{abstract}

*Correspondence: sookhoe72@kbri.re.kr

Department of Neural Development and Disease, Korea Brain Research Institute (KBRI), 61, Cheomdan-ro, Dong-gu, Daegu 41062, Republic of Korea action for the treatment of AD [2]. These cancer drugs include tyrosine kinase inhibitors (TKIs) such as dasatinib, masitinib, and imatinib, which have been shown to have therapeutic effects on the pathogenesis of AD [3-5].

Vatalanib, a small-molecule anticancer drug that inhibits angiogenesis (Fig. 1a), is a broad-spectrum TKI that exerts its effects by occupying the ATP-binding sites of vascular endothelial growth factor receptor 1-3 (VEGFR1-3), platelet-derived growth factor receptor $\alpha$ (PDGFR $\alpha$ ), and c-KIT [6]. VEGF and VEGFR have been implicated in angiogenesis as well as blood-brain-barrier (BBB) permeability and microglial chemotaxis in AD pathology [7-9]. VEGF levels are increased in the peripheral blood, cerebrospinal fluid, and microglia of patients with $\mathrm{AD}$ and are correlated with the clinical severity of $\mathrm{AD}[8,10,11]$, and VEGF and VEGFR expression are also increased in AD animal models [12]. However, the effect of vatalanib on tau phosphorylation and $A \beta$ accumulation in the $\mathrm{AD}$ brain has not been studied.

To investigate the effect of vatalanib on the AD brain, we administered $20 \mathrm{mg} / \mathrm{kg}$ of vatalanib daily for 14 days

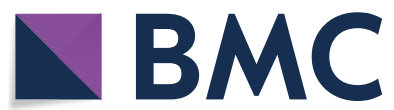

(c) The Author(s) 2020. This article is licensed under a Creative Commons Attribution 4.0 International License, which permits use, sharing, adaptation, distribution and reproduction in any medium or format, as long as you give appropriate credit to the original author(s) and the source, provide a link to the Creative Commons licence, and indicate if changes were made. The images or other third party material in this article are included in the article's Creative Commons licence, unless indicated otherwise in a credit line to the material. If material is not included in the article's Creative Commons licence and your intended use is not permitted by statutory regulation or exceeds the permitted use, you will need to obtain permission directly from the copyright holder. To view a copy of this licence, visit http://creativeco mmons.org/licenses/by/4.0/. The Creative Commons Public Domain Dedication waiver (http://creativecommons.org/publicdomain/ zero/1.0/) applies to the data made available in this article, unless otherwise stated in a credit line to the data. 


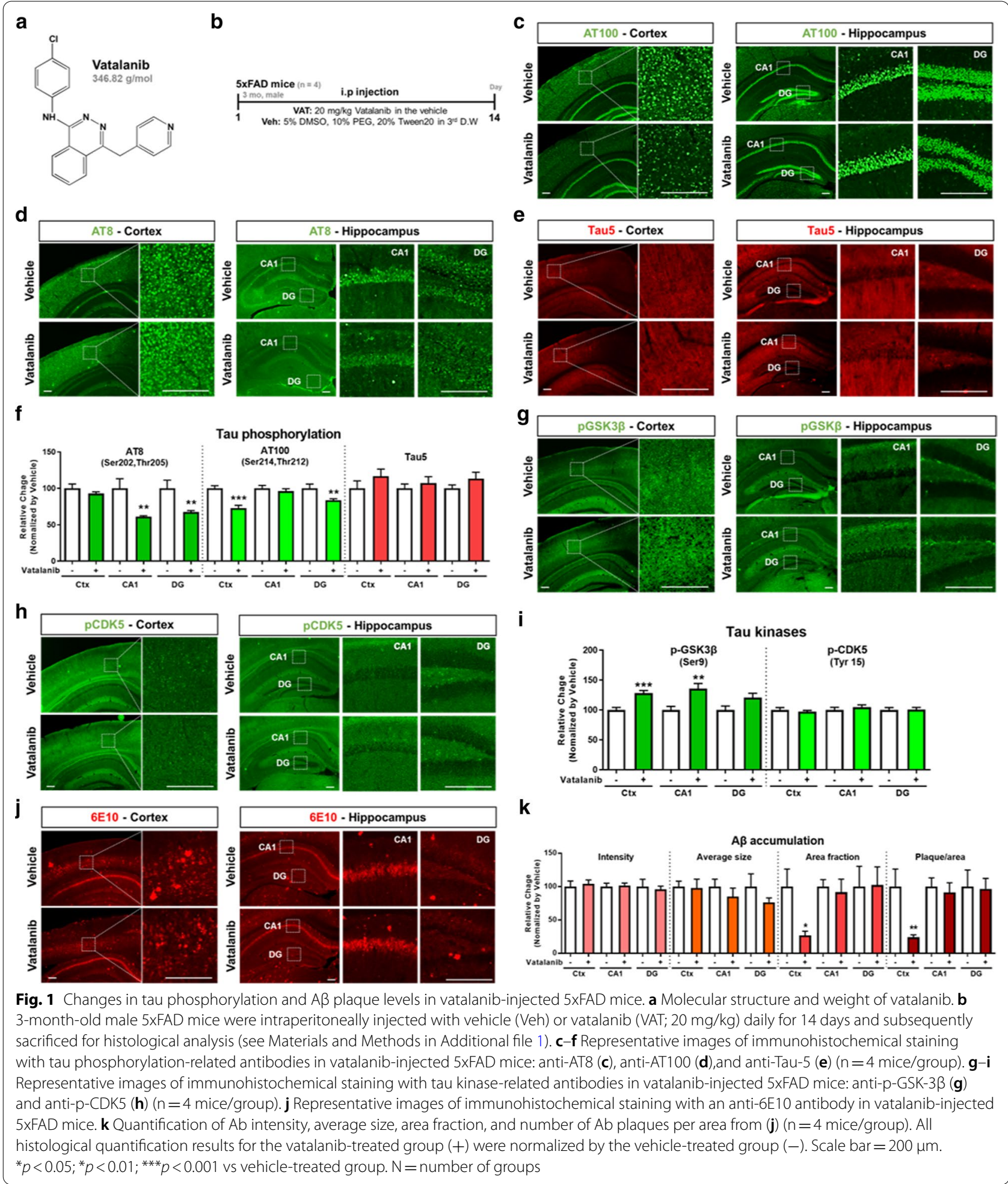

to 3-month-old 5xFAD mice, a model of AD (Fig. 1b). Eight hours after the last injection, the mice were fixed via sequential cardiac perfusion with $\mathrm{PBS}$ and $4 \%$ paraformaldehyde, and immunofluorescence staining was performed using AT100 (Ser ${ }^{202}$ and Thr $\left.{ }^{205}\right)$, AT8 $\left(\operatorname{Ser}^{214}\right.$ and $\mathrm{Thr}^{212}$ ), and Tau5 (total tau) antibodies to visualize tau phosphorylation (Fig. 1c-e). Histological quantification of the fluorescence intensity of tau phosphorylation 
(Fig. 1f) revealed a significant decrease in AT8 immunoreactivity in the hippocampus (CA1 and DG) of vatalanib-treated 5xFAD mice compared with vehicletreated 5xFAD mice (Fig. 1c, f). The fluorescence intensity of AT100 was also significantly decreased in the cortex and hippocampus DG of vatalanib-treated 5xFAD mice (Fig. 1d, f). However, the fluorescence intensity of Tau 5 was not altered by the administration of vatalanib (Fig. 1e, f). Thus, vatalanib administration in 5xFAD mice significantly reduced phospho-tau ${ }^{\text {Ser202, Thr205 }}$ and phospho-tau ${ }^{\text {Thr212, Ser214 }}$ without altering total tau levels.

To investigate the molecular mechanism by which vatalanib modulates tau phosphorylation in 5xFAD mice, immunofluorescence staining was performed with antibodies against p-GSK-3 $\beta$ and p-CDK5, the major molecules involved in tau phosphorylation (Fig. 1g, h). Histological quantification of the fluorescence intensity of tau kinases (Fig. 1i) revealed a significant increase in p-GSK- $3 \beta^{\text {Ser9 }}$ in the cortex and hippocampus CA1 of vatalanib-administered 5xFAD mice (Fig. 1g, i). However, another major tau kinase, $\mathrm{p}-\mathrm{CDK} 5$, was not altered by the administration of vatalanib in $5 \times$ FAD mice (Fig. $1 \mathrm{~h}$, i). It is well known that the constitutive activity of GSK-3 $\beta$ is inhibited by GSK-3 $\beta$ (Ser9) phosphorylation. Therefore, our results suggest that increased phosphorylation of GSK-3 $\beta$ (Ser9) may have contributed to the reduction of tau phosphorylation by vatalanib administration.

To investigate the accumulation of $A \beta$, another histopathological feature of $\mathrm{AD}$, immunofluorescence staining was performed in vatalanib-treated mice using a $6 \mathrm{E} 10$ antibody that labels $A \beta_{1-16}$ as an epitope (Fig. 1j). To evaluate the effect of vatalanib on $A \beta$ accumulation in $5 x F A D$ mice, the fluorescence intensity, area fraction and average size of $A \beta$ plaques and the number of $A \beta$ plaques per area were quantified based on 6E10 immunoreactivity (Fig. 1k). Although vatalanib administration did not alter the fluorescence intensity of $A \beta$ plaques in $5 x F A D$ mice, the area fraction of $A \beta$ plaques in the cortex was significantly reduced. The number of $A \beta$ plaques per area in the cortex was also significantly reduced in vatalanibadministered 5xFAD mice. However, the average size of $\mathrm{A} \beta$ plaques was not altered by vatalanib administration in 5xFAD mice (Fig. 1k).

In summary, we evaluated the effects of vatalanib on AD pathology in 5xFAD mice. Previous studies have demonstrated that both AT8- and AT100-labeled phospho-tau epitopes are elevated in the AD brain [13, 14]. In addition, 5xFAD mice have been reported to exhibit hyperphosphorylation of tau and decreased p-GSK-3 $\beta$ (Ser9) [15]. In the present study, administration of vatalanib attenuated tau phosphorylation at AT8 and AT100 in $5 \mathrm{xFAD}$ mice, and these changes were accompanied by increased GSK-3 $\beta^{\text {Ser9 }}$ phosphorylation (Fig. 1c-i). These results indicate that vatalanib differentially regulates tau phosphorylation by modulating the GSK-3 $\beta$ phosphorylation epitope in 5xFAD mice. While vatalanib administration had no effect on $A \beta$ fluorescence intensity or $A \beta$ plaque size, the number of $A \beta$ plaques excluding intracellular $A \beta$ in the cortex was significantly decreased in 5xFAD mice (Fig. 1k). Considering that 3- to 4-monthold 5xFAD mice predominantly accumulate $A \beta$ in the deep cortical layer and subiculum and not the hippocampus, it is reasonable that vatalanib has an inhibitory effect on $A \beta$ accumulation in the cortex [16]. It is possible that long-term administration of vatalanib might inhibit $A \beta$ accumulation according to age. Interestingly, a recent study found that $A \beta$ oligomers activate microglial cells in a tyrosine kinase-dependent manner [17]. In addition, since VEGF and VEGFR are involved in BBB permeability and microglial chemotaxis, future studies will address whether vatalanib affects neuroinflammatory responses and BBB integrity in 5xFAD mice [7-9]. Moreover, we will evaluate the effects of vatalanib on tauopathy, basal behavior, and cognitive impairment in a mouse model of AD (e.g., PS19 Tau Tg or 5xFAD mice) and identify the mechanism by which vatalanib alters tau phosphorylation as well as synaptic function. In conclusion, intraperitoneal injection of vatalanib in 3-month-old 5xFAD mice reduced $A \beta$ plaque levels and tau phosphorylation, and thus vatalanib may be a drug candidate for $\mathrm{Ab}$-and/or tau-associated diseases, including AD.

\section{Supplementary information}

Supplementary information accompanies this paper at https://doi. org/10.1186/s13041-020-00673-7.

Additional file 1.: Materials and methods.

\section{Abbreviations}

Aß: Amyloid B; AD: Alzheimer's disease; APP: Amyloid precursor protein; CDK5: Cyclin-dependent kinase-5; DG: Dentate gyrus; GSK-3 $\beta$ : Glycogen synthase kinase-3B; NFT: Neurofibrillary tangle; PDGFRa: Platelet-derived growth factor receptor a; TKI: Tyrosine kinase inhibitor; VEGF: Vascular endothelial growth factor; VEGFR: Vascular endothelial growth factor receptor.

\section{Acknowledgements}

Confocal microscopy (Nikon, TI-RCP) data were acquired at the Advanced Neural Imaging Center at the Korea Brain Research Institute (KBRI).

\section{Authors' contributions}

SGJ and HSH conceived and participated in the design of the study. SGJ, $H J L, H P$ and $\mathrm{KMH}$ performed in vivo experiments and histological analysis. SGJ and HSH wrote the manuscript. All authors read and approved the final manuscript.

\section{Funding}

This work was supported by the KBRI basic research program through KBR funded by the Ministry of Science, ICT \& Future Planning (Grant numbers 20-BR-02-15, 20-BR-02-20, and 20-BR-03-02) and the National Research Foundation of Korea (Grant number 2019R1A2B5B01070108). This study was partially supported by Whanin Pharm Co., Ltd. (Seoul, Republic of Korea) (Grant number 20190058) 


\section{Availability of data and materials}

The datasets generated during and/or analyzed during the current study are available from the corresponding author on reasonable request.

\section{Ethics approval and consent to participate}

All animal experiments were approved by the Institutional Animal Care and Use Committee at Korea Brain Research Institute (KBRI) (Assigned No. IACUC2016-0013, IACUC-19-00049, IACUC-19-00042).

\section{Consent for publication}

Not applicable.

\section{Competing interests}

The authors declare that they have no competing interests.

Received: 25 August 2020 Accepted: 18 September 2020

Published online: 25 September 2020

\section{References}

1. Querfurth HW, LaFerla FM. Alzheimer's disease. N Engl J Med. 2010;362:329-44

2. Lanni C, Masi M, Racchi M, Govoni S. Cancer and Alzheimer's disease inverse relationship: an age-associated diverging derailment of shared pathways. Mol Psychiatry. 2020. https://doi.org/10.1038/s4138 0-020-0760-2

3. Gagalo I, Rusiecka I, Kocic I. Tyrosine kinase inhibitor as a new therapy for ischemic stroke and other neurologic diseases: is there any hope for a better outcome? Curr Neuropharmacol. 2015;13:836-44.

4. Dhawan G, Combs CK. Inhibition of Src kinase activity attenuates amyloid associated microgliosis in a murine model of Alzheimer's disease. J Neuroinflamm. 2012;9:117.

5. Piette F, Belmin J, Vincent H, Schmidt N, Pariel S, Verny M, Marquis C, Mely J, Hugonot-Diener L, Kinet JP, et al. Masitinib as an adjunct therapy for mild-to-moderate Alzheimer's disease: a randomised, placebo-controlled phase 2 trial. Alzheimers Res Ther. 2011;3:16.

6. Wood JM, Bold G, Buchdunger E, Cozens R, Ferrari S, Frei J, Hofmann F, Mestan J, Mett H, O'Reilly T, et al. PTK787/ZK 222584, a novel and potent inhibitor of vascular endothelial growth factor receptor tyrosine kinases, impairs vascular endothelial growth factor-induced responses and tumor growth after oral administration. Cancer Res. 2000;60:2178-89.

7. Ruiz de Almodovar C, Lambrechts D, Mazzone M, Carmeliet P. Role and therapeutic potential of VEGF in the nervous system. Physiol Rev. 2009;89:607-48
8. Ryu JK, Cho T, Choi HB, Wang YT, McLarnon JG. Microglial VEGF receptor response is an integral chemotactic component in Alzheimer's disease pathology. J Neurosci. 2009;29:3-13.

9. Lange C, Storkebaum E, de Almodovar CR, Dewerchin M, Carmeliet P. Vascular endothelial growth factor: a neurovascular target in neurological diseases. Nat Rev Neurol. 2016;12:439-54.

10. Corsi MM, Licastro F, Porcellini E, Dogliotti G, Galliera E, Lamont JL, Innocenzi PJ, Fitzgerald SP. Reduced plasma levels of P-selectin and L-selectin in a pilot study from Alzheimer disease: relationship with neuro-degeneration. Biogerontology. 2011;12:451-4.

11. Cho SJ, Park MH, Han C, Yoon K, Koh YH. VEGFR2 alteration in Alzheimer's disease. Sci Rep. 2017;7:17713.

12. Muche A, Bigl M, Arendt T, Schliebs R. Expression of vascular endothelial growth factor (VEGF) mRNA, VEGF receptor 2 (Flk-1) mRNA, and of VEGF co-receptor neuropilin (Nrp)-1 mRNA in brain tissue of aging Tg2576 mice by in situ hybridization. Int J Dev Neurosci. 2015:43:25-34.

13. Zheng-Fischhofer Q, Biernat J, Mandelkow EM, Illenberger S, Godemann $\mathrm{R}$, Mandelkow E. Sequential phosphorylation of Tau by glycogen synthase kinase-3beta and protein kinase A at Thr212 and Ser214 generates the Alzheimer-specific epitope of antibody AT100 and requires a pairedhelical-filament-like conformation. Eur J Biochem. 1998;252:542-52.

14. Brownlees J, Irving NG, Brion JP, Gibb BJ, Wagner U, Woodgett J, Miller CC. Tau phosphorylation in transgenic mice expressing glycogen synthase kinase-3beta transgenes. NeuroReport. 1997;8:3251-5.

15. Kanno T, Tsuchiya A, Nishizaki T. Hyperphosphorylation of Tau at Ser396 occurs in the much earlier stage than appearance of learning and memory disorders in 5XFAD mice. Behav Brain Res. 2014:274:302-6.

16. Oakley H, Cole SL, Logan S, Maus E, Shao P, Craft J, Guillozet-Bongaarts A, Ohno M, Disterhoft J, Van Eldik L, et al. Intraneuronal beta-amyloid aggregates, neurodegeneration, and neuron loss in transgenic mice with five familial Alzheimer's disease mutations: potential factors in amyloid plaque formation. J Neurosci. 2006;26:10129-40.

17. Dhawan G, Floden AM, Combs CK. Amyloid-beta oligomers stimulate microglia through a tyrosine kinase dependent mechanism. Neurobiol Aging. 2012;33:2247-61.

\section{Publisher's Note}

Springer Nature remains neutral with regard to jurisdictional claims in published maps and institutional affiliations.
Ready to submit your research? Choose BMC and benefit from:

- fast, convenient online submission

- thorough peer review by experienced researchers in your field

- rapid publication on acceptance

- support for research data, including large and complex data types

- gold Open Access which fosters wider collaboration and increased citations

- maximum visibility for your research: over 100M website views per year

At BMC, research is always in progress.

Learn more biomedcentral.com/submissions 